\title{
61. DATA REPORT: CARBONATE SEDIMENTATION DURING THE MIOCENE AND PLIOCENE ON THE SOUTHERN KERGUELEN PLATEAU (SITE 751) ${ }^{1}$
}

\author{
William R. Howard ${ }^{2}$
}

\begin{abstract}
Detailed records of $\%$ calcium carbonate and calcium carbonate mass accumulation rate (MAR) for Site 751, located on the Southern Kerguelen Plateau, are presented. The shallow-water site contains a Neogene section with well-preserved carbonate sediments. These sediments record variations in the oceanography of the Antarctic surface waters. Carbonate sedimentation patterns reflect changing modes of biogenic sedimentation in the Miocene and Pliocene Antarctic Ocean.

Drilling at Site 751 recovered $166 \mathrm{~m}$ of early Miocene to Pleistocene siliceous and calcareous biogenic oozes. Three hiatuses, however, were detected: one between 14.8 and $12 \mathrm{Ma}$, another between 8.9 and $6.7 \mathrm{Ma}$, and a third between 5.08 and $5.36 \mathrm{Ma}$. Sedimentation rates were about $20 \mathrm{~m} / \mathrm{m}$.y. throughout the Miocene and $\leq 10 \mathrm{~m} / \mathrm{m}$.y. during the Pliocene and Pleistocene.

Key events in the depositional history are as follows: (1) a dramatic decrease in carbonate content, from $75 \%$ to near 0\%, near the Miocene/Pliocene boundary; and (2) minima in \% carbonate occur at 16.7, 16.3, 12.2, 11.7, and $9.8 \mathrm{Ma}$. The \% carbonate record shows variability about a mean of $\sim 70 \%$ and then a sharp drop near the Miocene/Pliocene boundary. The carbonate MAR record, however, exhibits a series of steplike changes throughout the Miocene. The terminal Miocene event in the carbonate MAR record is not as dramatic as in the \% carbonate record, as carbonate MARs had already decreased to about $15 \%$ of their middle Miocene values.
\end{abstract}

\section{INTRODUCTION}

One hole was drilled at Site 751 on the Southern Kerguelen Plateau, at $57^{\circ} 43.56^{\prime} \mathrm{S}, 79^{\circ} 48.89^{\prime} \mathrm{E}$, in $1633.8 \mathrm{~m}$ of water. The site lies about $7^{\circ} \mathrm{S}$ of the present-day Polar Front. The objectives in drilling this site were to obtain a continuous, highresolution Neogene section at a sufficiently shallow depth that carbonate sediments would be well preserved, and to obtain a paleoceanographic record of surface Antarctic water masses (Schlich, Wise, et al., 1989, "Site 751," pp. 339-373). The recovered section contains about $166 \mathrm{~m}$ of early Miocene to Pleistocene siliceous and calcareous biogenic oozes. The stratigraphy used in this report is based on shipboard biostratigraphy and paleomagnetic stratigraphy. Sedimentation rates average about $20 \mathrm{~m} / \mathrm{m} . \mathrm{y}$. throughout the Miocene and $\leq 10$ $\mathrm{m} / \mathrm{m}$.y. throughout the Pliocene and Pleistocene. The section is interrupted by at least three hiatuses in the middle and late Miocene.

\section{METHODS}

The weight percent $(\%)$ calcium carbonate data reported here were analyzed using a pressure gasometric system similar to that described by Jones and Kateiris (1983). The Brown University system differs from the Jones and Kateiris system in that it uses a differential pressure measurement at ambient pressure instead of absolute pressure in an evacuated system. Using this system, a precision of about $1 \%$ is regularly achieved. For ( $100 \%$ reagent grade) calcium carbonate standards associated with the data reported here, precision was $1.4 \%(1 \rho, N=101)$. For replicate analyses, precision was close to the precision of standards (mean difference between duplicates was $1.64 \% \pm 1.25, N=65$ ). Where two duplicates

\footnotetext{
${ }^{1}$ Wise, S. W., Jr., Schlich, R., et al., 1992. Proc. ODP, Sci. Results, 120: College Station, TX (Ocean Drilling Program).

2 Department of Geological Sciences, Brown University, Providence, RI 02912, U.S.A.
}

did not agree, a third replicate was run and the closest pair retained in the data set.

I have compared Ocean Drilling Program (ODP) shipboard carbonate analyses with this shore-based data set (Fig. 1). Shipboard \% carbonate analyses were carried out with a Coulometrics 5010 Coulometer coupled to a Coulometrics 5030 Carbonate Carbon analyzer. The precision (i.e., the standard deviation) of the shipboard replicate analyses is $\sim 1 \%$ (Schlich, Wise, et al., 1989). For samples that were analyzed by both laboratories $(N=76)$, the correlation between Brown and ODP shipboard \% carbonate analyses was $0.994\left(R^{2}\right)$. There was, however, a small but consistent offset: Brown measurements were approximately $2 \%$ higher than shipboard measurements. A similar comparison of ODP Leg 121 carbonate data found that the Brown University \% carbonate values were an average of $1 \%$ lower than ODP shipboard values (Farrell and Janecek, 1991). Because the offsets in both studies are small relative to the analytical precision of both laboratories, I have included ODP shipboard analyses in this study with no corrections.

Estimates of dry-bulk density are needed to calculate mass accumulation rates (MAR) for calcium carbonate. I estimated dry-bulk density from $\% \mathrm{CaCO}_{3}$ using shipboard discrete bulk density measurements on samples for which $\% \mathrm{CaCO}_{3}$ was also determined. For a total of 254 samples from Site 751 , the bulk density- $\% \mathrm{CaCO}_{3}$ relationship was best fit by the following second-order polynomial equation (Fig. 2):

$$
\begin{aligned}
\text { bulk density }\left(\mathrm{g} / \mathrm{cm}^{3}\right)= & 0.357+0.005 \cdot\left(\% \mathrm{CaCO}_{3}\right) \\
& +0.0000333 \cdot\left(\% \mathrm{CaCO}_{3}\right)^{2}
\end{aligned}
$$

The resulting multiple correlation coefficient $\left(R^{2}\right)$ is 0.91 , and the standard error of estimate for bulk density is 0.069 $\mathrm{g} / \mathrm{cm}^{3}$. This calibration is similar to other bulk density$\% \mathrm{CaCO}_{3}$ relationships in sediments primarily composed of calcium carbonate, biogenic silica, and clays (e.g., Curry and Lohmann, 1986; Clemens et al., 1987). 


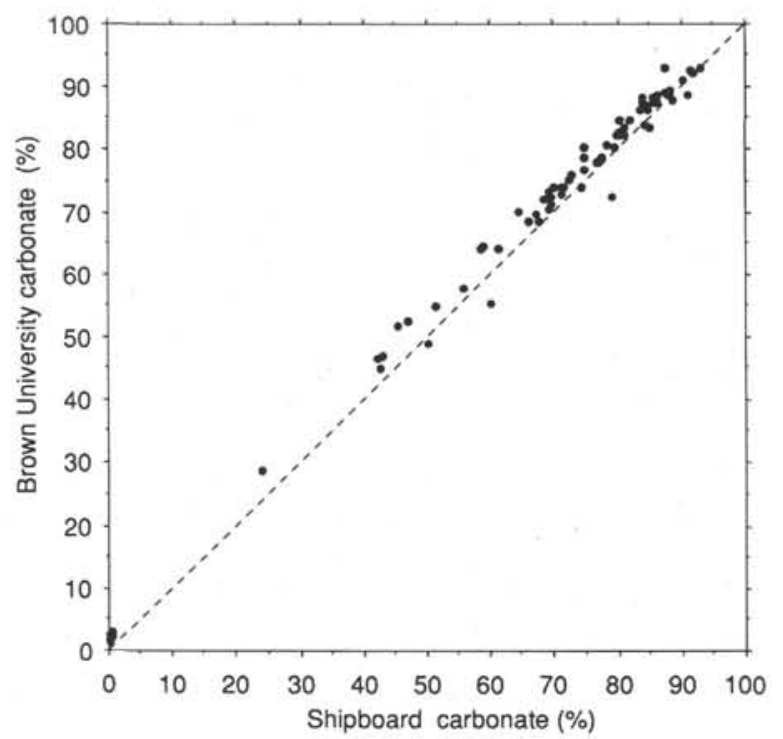

Figure 1. Correlation of $\mathrm{CaCO}_{3}$ from ODP shipboard and Brown University laboratories, $N=76, R^{2}=0.994$. Dashed line $=1: 1$ relationship.

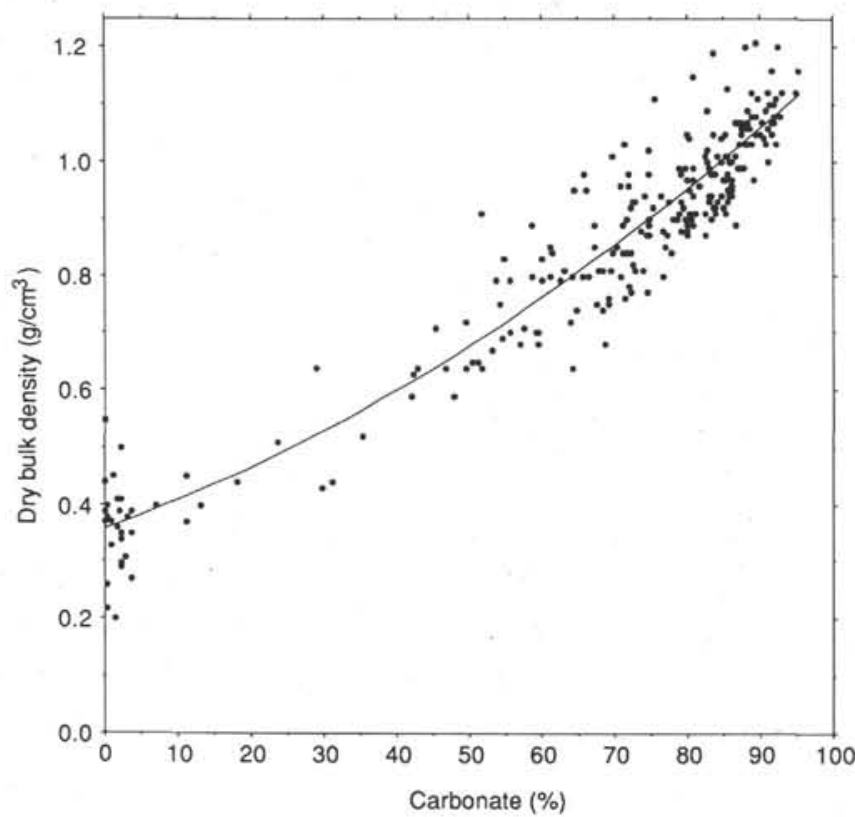

Figure 2. Calibration of discrete dry-bulk density estimates to percent carbonate. Solid line $=$ best-fit polynomial equation for dry-bulk density as a function of percent carbonate: bulk density $\left(\mathrm{g} / \mathrm{cm}^{3}\right)=$ $0.357+0.005 \cdot\left(\% \mathrm{CaCO}_{3}\right)+0.0000333 \cdot\left(\% \mathrm{CaCO}_{3}\right)^{2}, N=254, R^{2}=$ 0.91 , standard error of estimate $=0.069 \mathrm{~g} / \mathrm{cm}^{3}$.

\section{STRATIGRAPHY}

For purposes of this paper, I have followed shipboard bioand magnetostratigraphy (Schlich, Wise, et al., 1989, "Site 751,"'pp. 339-373), as confirmed by shore-based magnetobiostratigraphic studies (Berggren, this volume). Shipboard stratigraphy suggests that the hole drilled at Site 751 contains a record of sedimentation from the early Miocene through the Pleistocene, with three hiatuses.
Table 1. Age datums adopted for Site 751, based on shipboard magnetostratigraphy and biostratigraphy.

\begin{tabular}{rllc}
\hline $\begin{array}{r}\text { Depth } \\
\text { (mbsf) }\end{array}$ & \multicolumn{1}{c}{$\begin{array}{c}\text { Age } \\
(\mathrm{Ma})\end{array}$} & \multicolumn{1}{c}{ Event } & $\begin{array}{c}\text { Sedimentation } \\
\text { rate (m/m.y.) }\end{array}$ \\
\hline & & Top A. ingens & 2.7 \\
0.70 & 0.2 & Top N. praeinterfrigidaria & 19.2 \\
8.50 & 3.1 & Top Gilbert C (Thvera) & 17.5 \\
36.70 & 4.57 & Bottom Gilbert C (Thvera) & 4.1 \\
40.20 & 4.77 & Top Anomaly 3A & 10.9 \\
42.60 & 5.35 & Bottom Anomaly 3A & 4.4 \\
48.50 & 5.89 & Top Chron 6N & 10.2 \\
50.60 & 6.37 & Hiatus & 16.9 \\
54.26 & $6.73-8.92$ & Top Anomaly 5 & 20.0 \\
54.40 & \multicolumn{1}{c}{8.92} & Bottom Anomaly 5A & 12.1 \\
108.00 & 12.1 & Hiatus & 3.0 \\
109.04 & $12.15-14.3$ & Top Anomaly 5B & 16.1 \\
109.80 & 14.8 & Top Anomaly 5C & 19.6 \\
114.00 & 16.22 & Bottom Anomaly 5C & 19.6 \\
123.20 & 16.98 & Top Anomaly 5D & \\
132.70 & 17.57 & Top Anomaly 5E & \\
152.10 & 18.56 & &
\end{tabular}

Note: The sedimentation rate for the sediments above the first datum assumes an age of 0 for the mud line of the hole.

The uppermost hiatus lies between 5.08 and $5.36 \mathrm{Ma}$ and represents about $280,000 \mathrm{yr}$ of missing section. This hiatus includes part of the oldest reversed section of the Gilbert Chron and brackets the Miocene/Pliocene boundary. The exact age placement of the hiatus is hindered by the fact that it also brackets a core break (between Cores 120-751A-5H and $120-751 \mathrm{~A}-6 \mathrm{H}$ ) with approximately $1.2 \mathrm{~m}$ of missing sediment (because of the incomplete recovery in Core 120-751A-5H). At the sedimentation rates estimated for the intervals above and below the core break, this coring gap could account for as much as $80 \%$ of the estimated duration of the hiatus. In addition, ship heave under the adverse weather conditions encountered at Site 751 may have caused a larger coring gap than shipboard coring records indicate. Because of these uncertainties, sedimentation rate estimates throughout this interval must be considered suspect.

A second hiatus is indicated between $\sim 6.7$ and $8.9 \mathrm{Ma}$ within Core $120-751 \mathrm{~A}-7 \mathrm{H}$. Constraints on this hiatus are indications that the top of magnetic Chron $6 \mathrm{~N}$ was recovered within Core $120-751 \mathrm{~A}-6 \mathrm{H}$, and that the long normal interval within Core $120-751 \mathrm{~A}-7 \mathrm{H}$ comprises most of Anomaly 5 within Chron 5. I have placed this late Miocene hiatus between $6.73 \mathrm{Ma}$ at $54.26 \mathrm{mbsf}$ and $8.92 \mathrm{Ma}$ at $54.4 \mathrm{mbsf}$.

The third hiatus at Site 751 was identified within the middle Miocene between $\sim 12$ and $\sim 14.8 \mathrm{Ma}$. This hiatus is constrained by the identification of the bottom of magnetic Anomaly 5A at 108 mbsf and the top of Anomaly 5B at 109.8 mbsf.

Age datums for Site 751 adopted for this study and estimated sedimentation rates are given in Table 1.

\section{RESULTS}

Percent calcium carbonate as a function of depth (m below seafloor) at Site 751 is illustrated in Figure 3. Also shown are core recovery intervals for each of the 18 advanced piston cores (APC) taken at the site. Values of $\% \mathrm{CaCO}_{3}$ and sub-bottom depths are given in Table 2 (on microfiche in back pocket). Although shipboard records indicate nearly complete core recovery for the cores, extreme ship heave and the absence of an offset hole at the site make confident determination of true stratigraphic recovery impossible.

I have converted all sample depths to age by linearly interpolating between age datums (Table 1). I have expressed 


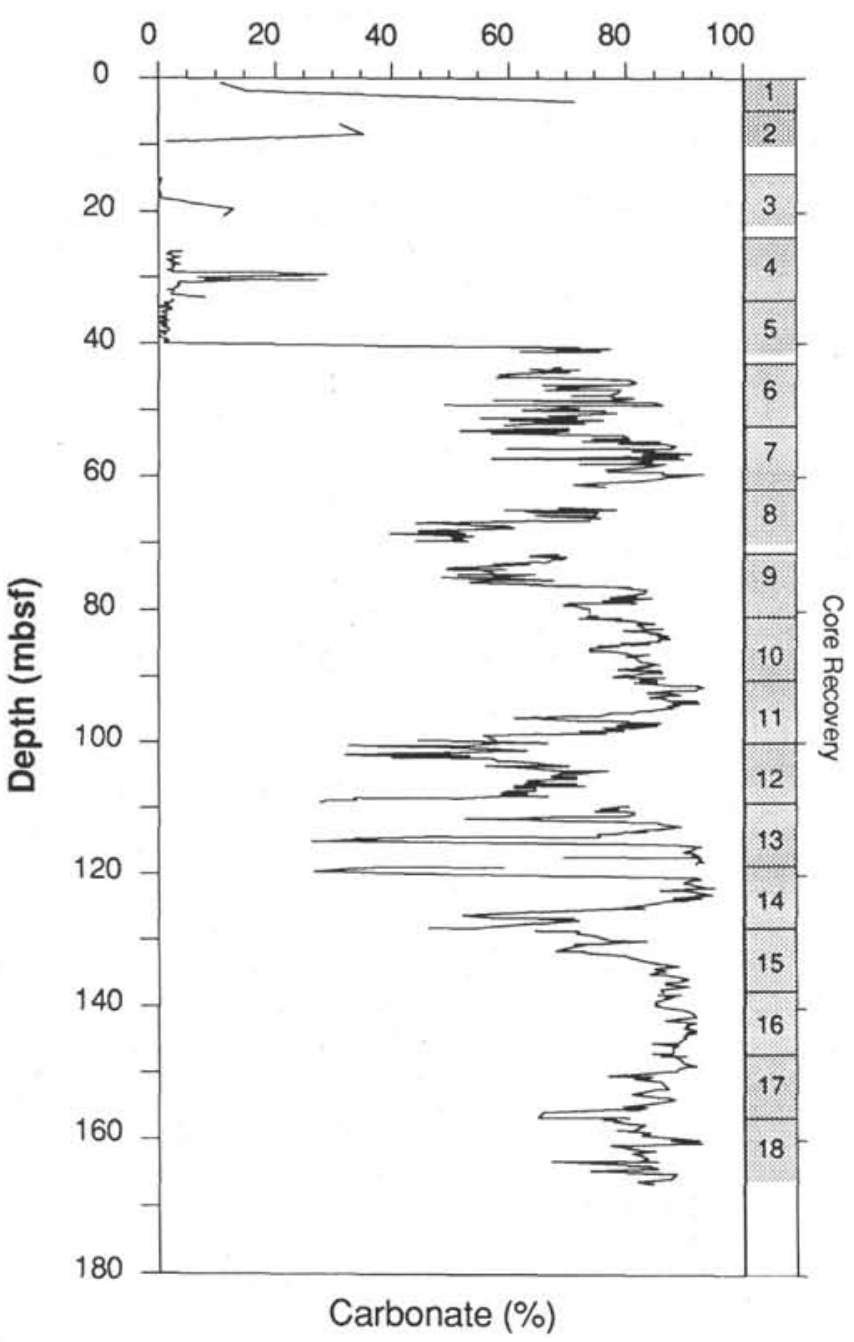

Figure 3. Variations in weight percent calcium carbonate as a function of depth beneath seafloor, Site 751. Gaps in plot represent core breaks. Gray shading represents recovery in each core.

sedimentation rates in $\mathrm{cm} / \mathrm{k} . \mathrm{y}$. Calcium carbonate mass accumulation rate (MAR) is calculated by

$\mathrm{CaCO}_{3} \mathrm{MAR}\left(\mathrm{g} / \mathrm{cm}^{2} / \mathrm{k} . \mathbf{y}.\right)=$ weight $\% \mathrm{CaCO}_{3}\left(\mathrm{~g}_{\mathrm{CaCO}_{3}} / \mathrm{g}_{\text {sed }}\right)$. dry-bulk density $\left(\mathrm{g} / \mathrm{cm}^{3}\right) \cdot$ linear sedimentation rate $(\mathrm{cm} / \mathrm{k}$.y. $)$.

The resulting variations in $\% \mathrm{CaCO}_{3}$ and $\mathrm{CaCO}_{3} \mathrm{MAR}$ as a function of age are shown in Figure 4.

Mean carbonate percentages in the Miocene interval from 19 through $5 \mathrm{Ma}$ are generally around $70 \%$, with variances around $10 \%$. In the early Pliocene an abrupt drop in \% carbonate occurred, from about $60 \%$ to $0 \%$. Carbonate percentages remained low (average around 3\%) through the early Pliocene of Site 751, and rose in the late Pliocene and Pleistocene.

Several low-carbonate events $(<50 \%)$ occurred through the early and middle Miocene. The first of these lows occurred at $17.2 \mathrm{Ma}$, followed by two more extreme events (carbonate around $30 \%$ ) at 16.8 and $16.3 \mathrm{Ma}$. Following the middle Miocene hiatus, three low-carbonate intervals occurred at $\sim 12.2,11.7$, and $9.8 \mathrm{Ma}$.

Carbonate mass accumulation rates, in contrast to percentages (Fig. 4), show a series of steplike variations. Mean
$\mathrm{CaCO}_{3}$ MAR is $1.75 \mathrm{~g} / \mathrm{cm}^{2} / \mathrm{k} . \mathrm{y}$. for the interval from 19 through $17.5 \mathrm{Ma}$, and about $1 \mathrm{~g} / \mathrm{cm}^{2} / \mathrm{k}$.y. for the interval from 17.5 through $16 \mathrm{Ma}$. $\mathrm{CaCO}_{3}$ MAR drops to about $0.2 \mathrm{~g} / \mathrm{cm}^{2} /$ k.y. during the period from 16.2 to $14.8 \mathrm{Ma}$, although uncertain ties in stratigraphic control for the lower bound of the hiatus at that time make the sedimentation rate estimates tentative. Carbonate MARs averaged approximately 1.0 $\mathrm{g} / \mathrm{cm}^{2} / \mathrm{k}$.y. throughout the period from 12 to $9 \mathrm{Ma}$. Throughout this interval, MARs varied from a maximum of $2 \mathrm{~g} / \mathrm{cm}^{2} / \mathrm{k}$.y. at $11 \mathrm{Ma}$ to minima of $<0.5 \mathrm{~g} / \mathrm{cm}^{2} / \mathrm{k}$.y. at 11.5 and $9.5 \mathrm{Ma}$. From 6.7 to $5 \mathrm{Ma}$, carbonate MAR averaged about $0.5 \mathrm{~g} / \mathrm{cm}^{2} / \mathrm{k} . \mathrm{y}$. From $5 \mathrm{Ma}$ to the top of the section, carbonate MAR never rose above $0.25 \mathrm{~g} / \mathrm{cm}^{2} / \mathrm{k} . \mathrm{y}$.

\section{DISCUSSION}

Variations in carbonate percent in pelagic sediments reflect a balance of three processes: (1) calcium carbonate production in surface waters, (2) seabed dissolution of carbonate, and (3) dilution of carbonate in sediments by sedimentation of noncarbonate components such as clay, volcanic ash, or biogenic opal (e.g., Volat et al., 1980). The shallow depth of Site 751 $(1634 \mathrm{~m})$ makes it unlikely that carbonate dissolution has affected this site. Shipboard descriptions indicate that the input of terrigenous sediments (volcanic ash and ice-rafted debris) has been minor except during brief intervals of the Pliocene. Thus, I interpret variations in \% carbonate and carbonate MAR in terms of changing carbonate productivity and dilution by biogenic silica. Smear-slide descriptions indicate that the dominant sedimentary components are calcareous nannofossils and diatoms. Variations in the mode of biogenic sedimentation are mainly characterized by changes in the relative dominance of silica vs. carbonate.

The most striking event recorded at this site is the drop in carbonate at about $\mathbf{4 0} \mathrm{mbsf}$ (latest Miocene-early Pliocene). I interpret this sedimentologic change as a fundamental shift in the mode of biogenic particle production, reflecting an ecological change in Southern Ocean surface waters. This late Miocene-early Pliocene shift in sedimentation appears to have been a widespread phenomenon in the Southern Ocean (Kennett, 1977; Brewster, 1980; Barker et al., 1988; Ciesielski et al., 1988; Barron et al., 1989). Such a shift has important implications for the chemistry and circulation of Antarctic surface-water masses.

\section{CONCLUSION}

Site 751 provides a record of biogenic carbonate sedimentation for the high-latitude Southern Ocean during the Neogene. Because of the shallow depth of the site $(1634 \mathrm{~m}), \mathrm{I}$ assume that carbonate variations are a result of the varying relative influences of carbonate and silica productivity, not of variations in carbonate preservation.

The $\%$ carbonate record shows variability about a mean of $\sim 70 \%$ throughout the Miocene, with minima in \% carbonate occurring at $\sim 16.7,16.3,12.2,11.7$, and $9.8 \mathrm{Ma}$. A dramatic decrease in carbonate content, from $75 \%$ to near $0 \%$, occurs near the Miocene/Pliocene boundary. The carbonate MAR record, in contrast, shows a series of steps throughout the Miocene. The latest Miocene reduction in carbonate MAR record suggests a smaller change in carbonate accumulation than does the \% carbonate record. Carbonate MARs show a more gradual series of decreases throughout the Miocene, to about $15 \%$ of their middle Miocene values by latest Miocene time.

\section{ACKNOWLEDGMENTS}

I would like to thank the master, crew, and technical staff aboard the JOIDES Resolution for their efforts at sea. W. Kang and $\mathrm{H}$. Koutrouvelis provided laboratory assistance at 


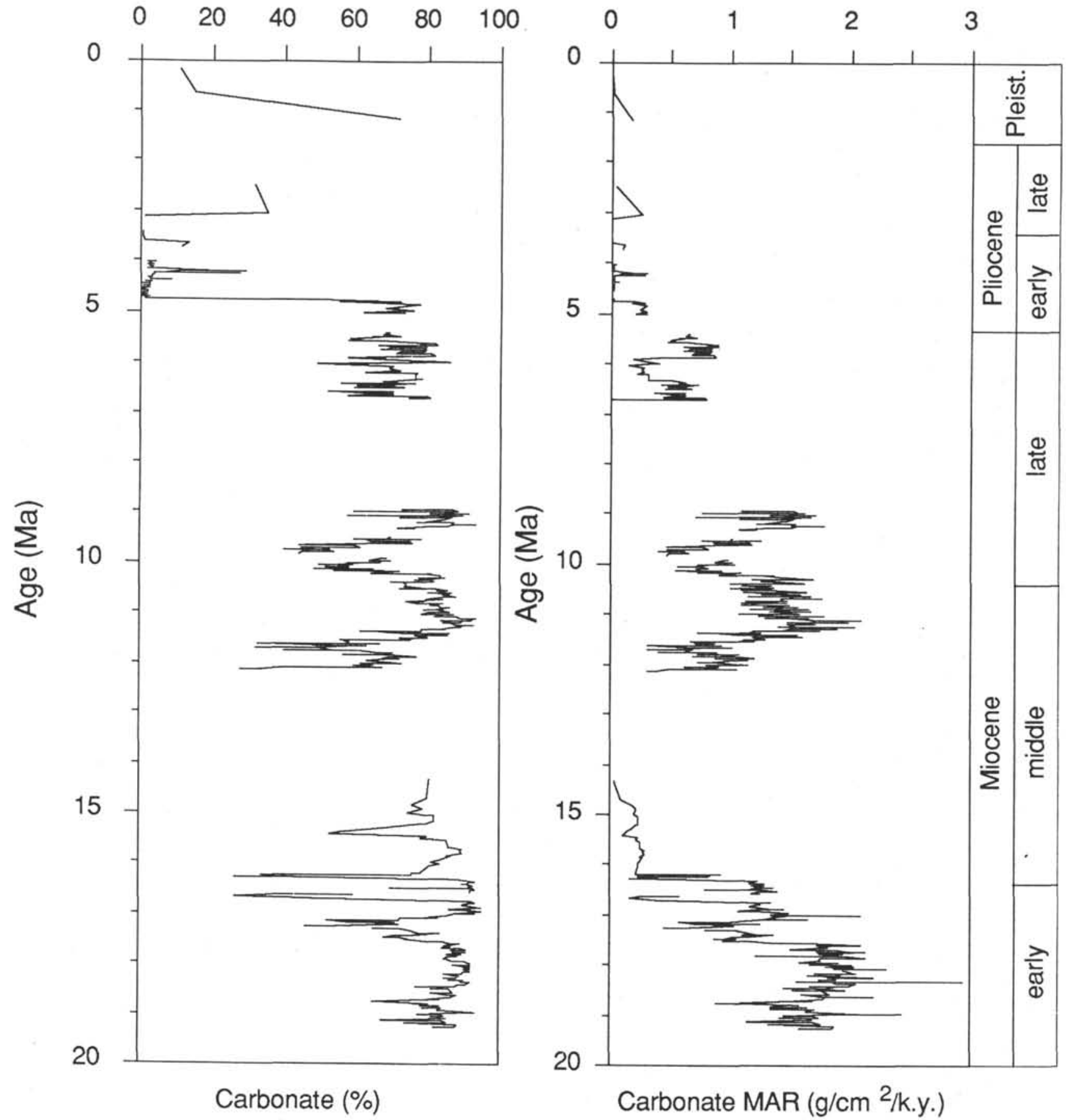

Figure 4. Variations in $\% \mathrm{CaCO}_{3}$ and $\mathrm{CaCO}_{3}$ mass accumulation rate (MAR) as a function of age, Site 751 .

Brown University. J. Farrell and L. Peterson provided thorough reviews. This work was supported by a JOI-USSAC grant.

\section{REFERENCES}

Barker, P. F., and Kennett, J. P., 1988. Weddell Sea palaeoceanography: preliminary results of ODP Leg 113. Palaeogeogr., Palaeoclimatol., Palaeoecol., 67:75-102.

Barron, J., Larsen, B., et al., 1989. Proc. ODP, Init. Repts., 119: College Station, TX (Ocean Drilling Program).

Brewster, N. A., 1980. Cenozoic biogenic silica sedimentation in the Antarctic Ocean. Geol. Soc. Am. Bull., 91:337-347.
Ciesielski, P. F., Kristoffersen, Y., et al., 1988. Proc. ODP, Init. Repts., 114: Ocean Drilling Program (College Station, TX).

Clemens, S. C., Prell, W. L., and Howard, W. R., 1987. Retrospective bulk density estimates from Southeast Indian Ocean sediments: comparison of water-loss and chlorine-ion methods. Mar. Geol., 76:57-70.

Curry, W. B., and Lohmann, G. P., 1986. Late Quaternary carbonate sedimentation at the Sierra Leone Rise (eastern equatorial Atlantic). Mar. Geol., 70:223-250.

Farrell, J. W., and Janecek, T. R., 1991. Late Neogene paleoceanography and paleoclimatology of the northeast Indian Ocean (Site 758). In Weissel, J., Peirce, J., Taylor, E., Alt, J., et al., Proc. ODP, Sci. Results, 121: College Station, TX (Ocean Drilling Program). 
Jones, G. A., and Kateiris, P., 1983. A vacuum-gasometric technique for rapid and precise analysis of calcium carbonate in sediments and soils. J. Sediment. Petrol., 53:655-659.

Kennett, J. P., 1977. Cenozoic evolution of Antarctic glaciation, the circum-antarctic ocean, and their impact on global paleoceanography. J. Geophys. Res., 82:3843-3860.

Schlich, R., Wise, S. W., Jr., et al., Proc. ODP, Init. Repts., 120 College Station, TX (Ocean Drilling Program).
Volat, J. L., Pastouret, L., and Vergnaud-Grazzini, C., 1980. Dissolution and carbonate fluctuations in Pleistocene deep-sea cores: a review. Mar. Geol., 34:1-28.

Date of initial receipt: 19 December 1990

Date of acceptance: 15 February 1991

Ms 120B-206 